\title{
THE CONDITIONS OF DESIGNING THE EDUCATIONAL PROCESS OF FUTURE ELECTRICAL PROFILE SPECIALISTS TRAINING
}

\section{Kolodiichuk L. S.}

\section{INTRODUCTION}

The state of training of future specialists in electrotechnical profile testifies that nowadays agrotechnical education is going not through its best time. Electrical engineering training in higher education institutions does not fully meet the requirements of employers and the level of pan-European education standards. However, modern information society requires training of self-employed and socially active engineering staff, capable of properly fulfilling professional responsibilities, which indicates a high level of professional competence. Practice shows that agrotechnical institutions do not always cope with training such professionals who are competitive in the labor market.

Hence the question arrives of the priority of introducing changes in the training of future specialists in the electrotechnical profile. In particular, identifying the conditions of projecting and improving the educational process.

Detecting pedagogical conditions, first of all, we focused on the concept of pedagogical projecting, which corresponds to the set goals in the education (education, development) and professional self-development of the teacher. Pedagogical projecting should be understood to-day as a component of professional activity of a teacher, which involves pedagogical actions that determine the further interaction of the subjects of the educational process ${ }^{1}$.

In this context, resolving the main contradiction of the educational process, which is caused by the incongruity between the demand in recruiting competent graduates of technical specialties and the lack of a holistic system of projecting the educational process aimed at forming their professional competencies, it was decided on the feasibility of introducing organizational and pedagogical conditions.

\footnotetext{
${ }^{1}$ Чорнобрива Н.В. Підготовка майбутніх фельдшерів до професійної діяльності у процесі виробничої практики : дис. ... к-та пед. наук: 13.00.04. Хмельницький, 2018. 206.
} 
We concretize this contradiction with respect to the basic parameters of the educational process (semantic, procedural and resultant components). The most acute are the incongruity of the volume and content of didactic material to the modern requirements of the development of electrical engineering. This requires correcting the content of training future specialists, on peculiarities of which and on specifics of the tasks to be solved, the choice of optimal teaching methods, which together determine the projecting of the effective component of the educational process, depends. Therefore, the purpose of the work is to study and substantiate the organizational and pedagogical conditions of projecting the educational process of training future specialists of the electrotechnical profile in the agrotechnical institution of higher education.

However, the solution of this problem is connected to a number of difficulties, which are due to the following reasons: ambiguity of the scientists' understanding of the definition of "organizational and pedagogical conditions"; limited analysis of the influence of identified factors on various aspects of the projecting of the educational process; underestimation of the specifics of the electrical engineering industry. In order to overcome the outlined phenomena in our study, we consider it appropriate to address the following issues: to make a choice of conditions and to construct a model of interconnection with the parameters of the educational process of training future specialists in the electrical engineering profile; to justify organizational and pedagogical conditions of projecting the components of the educational process.

\section{Choice of organizational and pedagogical conditions and correlation with the parameters of the educational process}

By defining organizational and pedagogical conditions, first of all, let's distinguish the essence of the concept of "condition". After all, in modern pedagogical studies the term "condition" is used quite often while characterizing pedagogical systems.

This is emphasized on by $\mathrm{R}$. Horbatiuk ${ }^{2}$, who is convinced that functioning and development of any systems is based on an organized sequence of measures, the effectiveness of which depends on compliance with a set of necessary conditions.

That is, modelling a system that will ensure the effective design of the educational process for the training of future specialists in the electrical engineering profile is impossible without studying and reasoning the

\footnotetext{
${ }^{2}$ Горбатюк Р.М. Теоретико-методичні засади професійної підготовки майбутніх інженерів-педагогів комп'ютерного профілю : автореф. дис. ... д-ра пед. наук : 13.00.04. Тернопіль, 2011. С. 34.
} 
appropriate conditions that have an active impact on the subjects of designing and the parameters of the educational process.

The Modern Explanatory Dictionary of the Ukrainian Language by L.P. Oleksiienko and O.L. Shumeilo defines conditions as a set of rules, regulations and the requirements, the compliance of which is necessary to ensure something ${ }^{3}$. Philosophical dictionary ${ }^{4}$ explains conditions as internal properties of an object and factors, external to it, which being separate from the immediate causes, cannot produce consequences, but they are a favorable and necessary environment for the development of cause and effect interactions. Conditions are a set of reasons, as D. Kilderov notes, which can affect the dynamics of processes and the final outcomes ${ }^{5}$.

In the context of our study, it is also of interest to define the concept of "condition", which has an organizational and pedagogical basis. The problem of organizational and pedagogical conditions has acquired colour in the writings of many scholars. The definition of pedagogical factors that contribute to the process of effective learning was addressed to by scholars: R. Horbatiuk, O. Hulai, V. Humeniuk, D. Kilderov, O. Kryvyliova, O. Molchaniuk, M. Nedbai, O. Romanyshyna, N. Chornobryva, O. Yaroshynska and others.

When considering the design of the educational environment for the training of future specialists, E. Yaroshynska (2015) defined pedagogical conditions as a set of interrelated and interdependent objective opportunities that ensure the purposeful and systematic coordination of the actions of all its subjects ${ }^{6}$.

In providing competency orientation for future teachers of vocational education institutions, O. Kryvyliova (2018) emphasizes the role of organizational and pedagogical conditions as a catalyst for psychological and pedagogical training, which determine its results and objectively ensure the possibility of their achievement ${ }^{7}$.

3 Олексієнко Л.П., Шумейло О.Л. Сучасний тлумачний словник украӥнськой мови. Київ : Кобза, 2002. С. 481.

4 Філософія словник. URL: https://arm.naiau.kiev.ua/books/filosofia-30012017/ info/slovnyk.html (дата звернення: 27.04.2020).

${ }^{5}$ Кільдеров Д.Е. Теоретичні і методичні засади забезпечення якості підготовки майбутніх учителів технологій на основі інтегрованого навчання : дис. ... д-ра пед. Наук : 13.00.04. Вінниця, 2018. С. 245.

6 Ярошинська О.О. Теоретико-методичні засади проектування освітнього середовища професійної підготовки майбутніх учителів початкової школи : дис. ... д-ра пед. Наук : 13.00.04. Умань, 2015. С. 235.

${ }^{7}$ Кривильова О.А. Проектування психолого-педагогічної підготовки майбутніх викладачів професійно-технічних навчальних закладів : дис. ... д-ра пед. наук : 13.00.04. Бердянськ, 2018. С. 305. 
Scholar N. Chornobryva (2018), researching the training of future specialists for professional activity in the process of internship, determines the pedagogical conditions as a set of special-professional circumstances, developing propellants, effective factors in the purposeful content of educational activity with the system of methods, means and forms ${ }^{8}$.

In the context of theoretical and methodological foundations of providing the quality of training of future specialists on the basis of integrated learning, D. Kilderov (2018) considers pedagogical conditions as a set of opportunities of educational and material and spatial environment that negatively or positively affect its functioning ${ }^{9}$.

We consider appropriate the definition of R. Horbatiuk (2018), who, when examining the pedagogical conditions of forming the graphic competence of computer-engineer educators, defined the conditions as a set of external and internal psychological and pedagogical factors intended to influence the educational process in order to achieve a specific pedagogical goal ${ }^{10}$.

Scholar V. Humeniuk (2016), when studying the conditions of obtaining higher education by foreign students in Ukraine, drew attention to organizational and pedagogical conditions as a complex of interrelated circumstances and ways of organization, that provide the positive dynamics and quality of the process ${ }^{11}$. M. Nedbai adheres to a similar interpretation: pedagogical conditions are "a set of factors or circumstances that create an environment in which the learning process runs most effectively"12.

Scholar N. Volkova considers external conditions such as acting through internal ones and characterized by a unity. At the same time, external and internal conditions are inherently the opposites that determine the process of formation of personality ${ }^{13}$.

\footnotetext{
${ }^{8}$ Чорнобрива Н.В. Підготовка майбутніх фельдшерів до професійної діяльності у процесі виробничої практики : дис. ... к-та пед. наук: 13.00.04. Хмельницький, 2018. C. 102.

${ }^{9}$ Кільдеров Д.Е. Теоретичні і методичні засади забезпечення якості підготовки майбутніх учителів технологій на основі інтегрованого навчання : дис. ... д-ра пед. наук : 13.00.04. Вінниця, 2018. С. 247.

10 Горбатюк Р.М. Теоретико-методичні засади професійної підготовки майбутніх інженерів-педагогів комп'ютерного профілю : автореф. дис. ... д-ра пед. наук : 13.00.04. Тернопіль, 2011. С. 36.

11 Гуменюк В.В. Організаційно-педагогічні умови здобуття іноземними студентами вищої медичної освіти в Україні (середина XX - початок XXI століття) : автореф. дис. ... к-та пед. наук : 13.00.01. Хмельницький, 2016. С. 4.

Недбай М.П. Організаційно-педагогічні умови оптимізації викладання технічних дисциплін курсантами гуманітарного напряму підготовки. Збірник наукових праць. Педагогічні і психологічні науки. Хмельницький : НАДПС України, 2005. № 33. C. 87.

${ }_{13}$ Волкова Н.П. Педагогіка: посібник. Київ : Академія, 2002. С. 41. 
In the ways of developing the research competence of future specialists in agricultural engineering in the process of studying agricultural machinery I. Butsyk (2019) argues that the organizational and pedagogical conditions are specially created circumstances that provide purposeful, orderly and consistent influence on the personality of factors that are necessary and sufficient to achieve the goal ${ }^{14}$.

Thus, the analysis of pedagogical literature and dictionaries showed that in fact the organizational and pedagogical conditions can be considered as circumstances for the development of causal links in designing a holistic educational process of training future electrical specialists based on the selection of its components.

The processing of the scholastic researches of the above mentioned authors, made it possible to reveal a complex of essential organizational and pedagogical conditions to which we can attribute:

- purposeful formation of students' positive motivation (R.M. Horbatiuk);

- systematic monitoring of the level of formation of professional competence (R.M. Horbatiuk);

- social adaptation of students to interaction with the environment (E.A. Yaroshynska);

- increasing the interest of future specialists in professional activities (N.V. Chornobryva);

- introduction of computer technologies in the process of training specialists (N.V. Chornobryva);

- intensification of independent activity on the basis of competence approach (N.V. Chornobryva);

- focus on the formation of professional competence (O.A. Kryvylova);

- motivational readiness of teachers for pedagogical projecting (N.A. Zharkova);

- information and material support (M.P. Nedbai);

- gradual formation of readiness of future specialists for their professional activity in the process of internship (N.V. Chornobryva).

Having analysed the pedagogical conditions mentioned above, choosing the most effective ways that create a potent impact on a successful projecting of the educational process, the arguments presented in the work of M. Nedbai were taken into account ${ }^{15}$.

14 Буцик I.М. Шляхи забезпечення організаційно-педагогічних умов розвитку дослідницької компетентності майбутніх фахівців 3 агроінженерії в процесі вивчення сільськогосподарських машин. Інноваційна педагогіка. Педагогічні науки. Одеса, 2019. Вип. 11, том 1. С. 57.

15 Недбай М.П. Організаційно-педагогічні умови оптимізації викладання технічних дисциплін курсантами гуманітарного напряму підготовки. Збірник наукових праць. Педагогічні і психологічні науки. Хмельницький : НАДПС України, 2005. № 33. C. 88. 
For this purpose the schematic model of projecting the educational process of training future specialists of electrotechnical profile is developed, fig. 1. After all, the purpose of a model is to solve the problem of studying the properties of an object through its substitute.

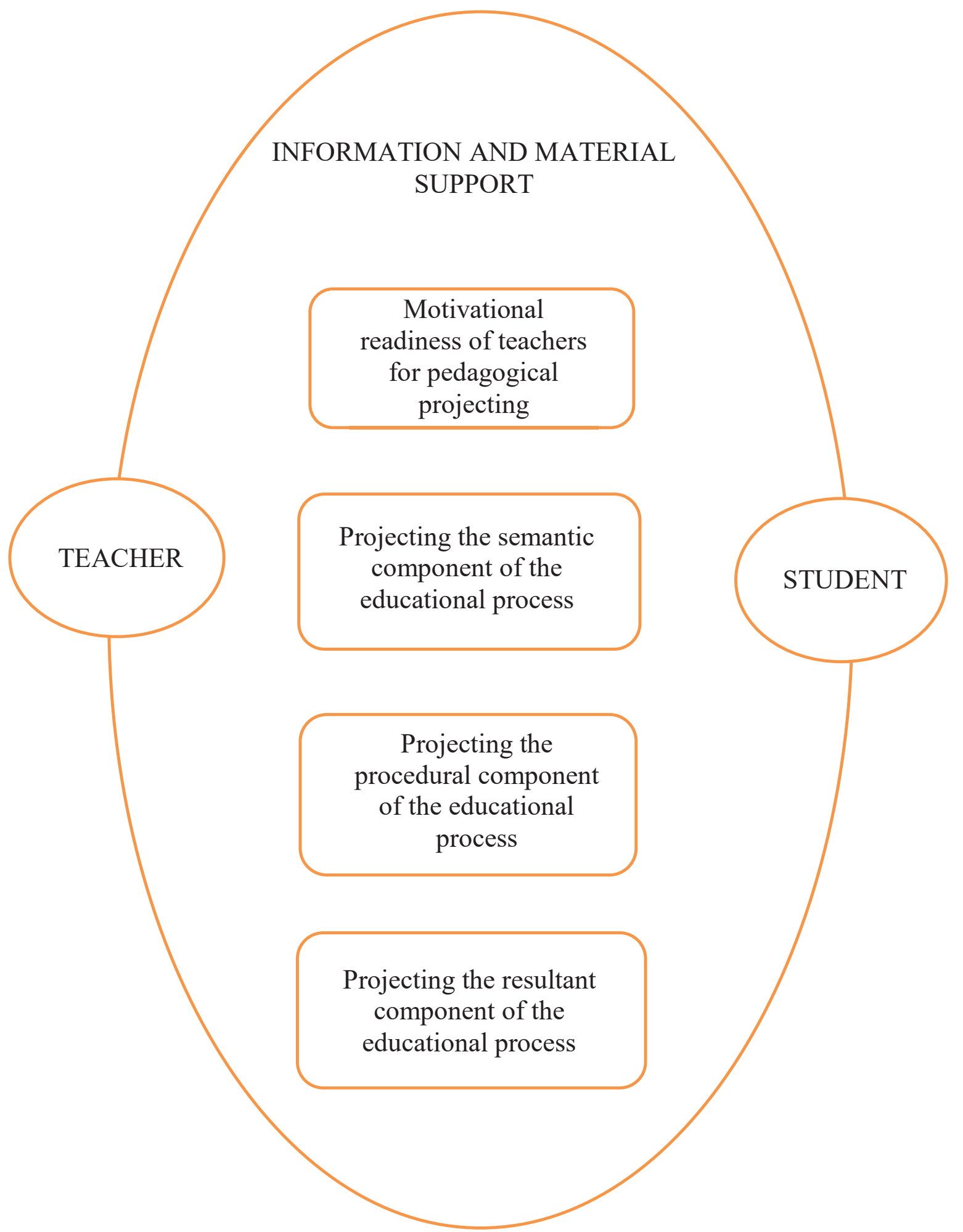

Fig. 1. The model of projecting the educational process of training future specialists of electrotechnical profile 
This model aims at designing the parameters of the educational process in the agricultural institution of higher education and suggests the implementation of interrelated components: motivational; semantic; procedural; resultant; informational.

In this context, the choice of organizational and pedagogical projecting conditions was fulfilled on the basis of the developed model of projecting the educational process, analysis of scholastic and pedagogical sources and personal conclusions. The results of theoretical research and long-term observations made it possible to distinguish 5 organizational and pedagogical conditions relating to designing the educational process of future specialists in the electrotechnical profile training.

These include:

1) formation of motivational readiness of teachers of agrotechnical institutions of higher education;

2) designing the system of knowledge of students in the electrotechnical disciplines that form the basis of professional training, taking into account the features of the electrotechnical specialty in the conditions of the agricultural sector of the economy;

3 ) designing the system of skills by modern methodological means, which is based on the combination of traditional and innovative forms of learning (modular system, distance learning, project (interactive methods);

4) gradual formation of professional competence of the future specialist of electrical engineering profile on the basis of the competence approach, which involves modeling of future professional activity of specialists, independent work of students and step-by-step assessment of knowledge;

5) information support of the educational process due to expanding the functions of information technologies.

Considering the results of our previous research on the components of the educational process, we believe that there is a certain relationship between organizational and pedagogical conditions of projecting and parameters of the educational process.

Particularly in practical terms, considering the conditions as circumstances aimed at achieving the goals of the system of projecting of the educational process of future specialists of electrotechnical profile training, the parametric model of interrelation of organizational and pedagogical conditions of designing of educational process is developed, Fig. 2.

The first condition will determine the motives of the project activity, the second - the semantic component of the design, the third - the procedure, the fourth - the result, the fifth - the means with the help of which we will achieve the implementation of the educational process design system. Determining among the conditions, in our opinion, is the resultant one, which is aimed at forming the professional competence of the future specialist of electrical engineering profile. 


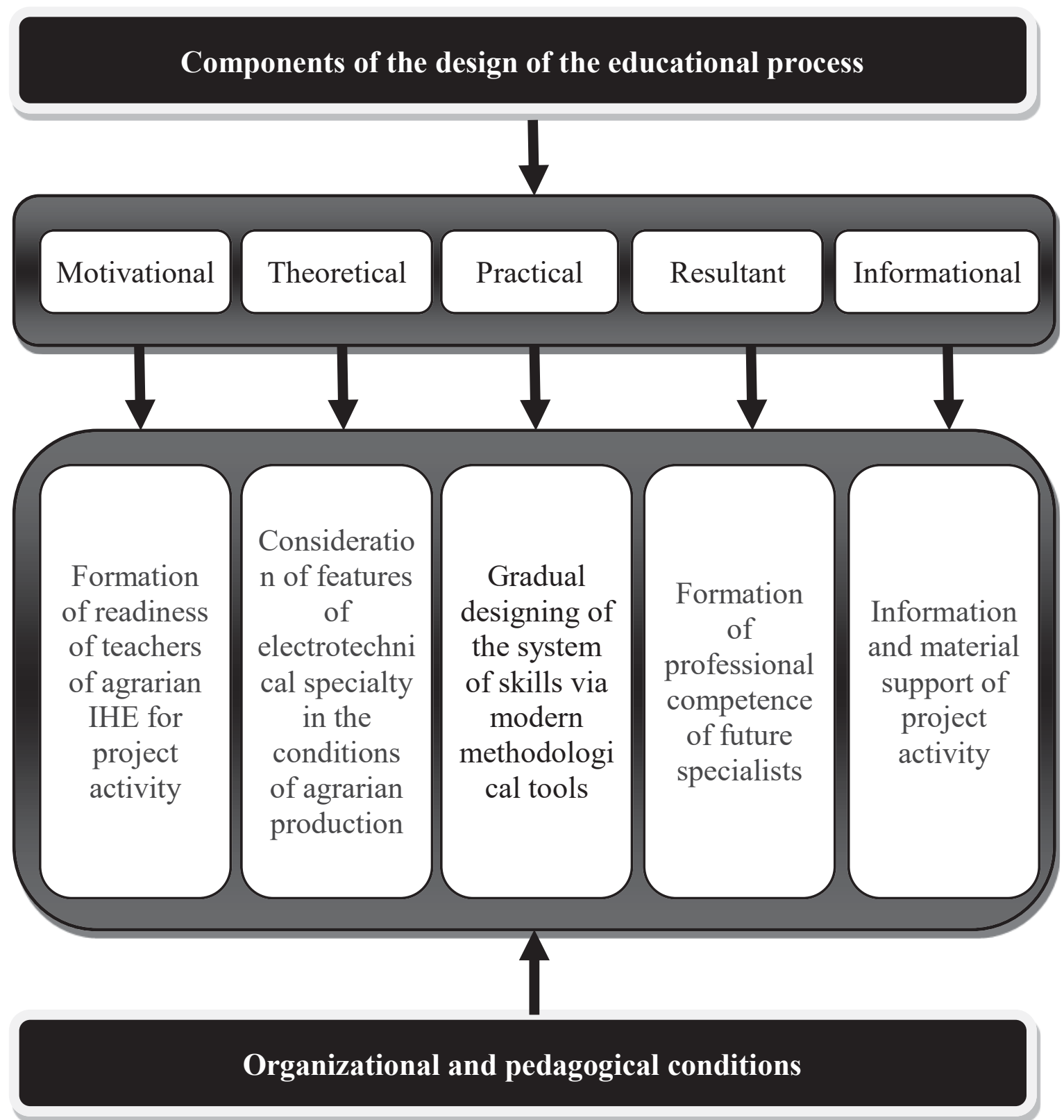

Fig. 2. Relationship between organizational and pedagogical conditions and components of the design of the educational process of future specialists of electrotechnical profile training

\section{Substantiation of organizational and pedagogical conditions for designing components of the educational process}

The study revealed that each of the isolated pedagogical conditions had a significant impact on the design of the components of the educational process in the agricultural institution of higher education. Of course, a more significant effect is manifested in the implementation of them in the complex. Discovering such a set of organizational and pedagogical conditions in the design of the educational process, we sought to achieve the most productive correlation of the content of professional training of future 
specialists in the electrotechnical profile with the methods of their educational and cognitive activity and thus significantly increase the level of professional competence of such graduates in agro-education.

Considering the organizational and pedagogical conditions of designing the educational process, first of all, let's turn to the motivational sphere of its participants. After all, it is known from psychology that any activity is determined and regulated by motives, that is, the basis for action. The question of teacher's motivational readiness for pedagogical design, as N. Zharkova notes ${ }^{16}$, is considered as a problem for the teacher to acquire adequate personal meaning of professional activity. Further, the author warns that the imbalance in the motives of the participants of the educational process arising at the same time can lead to a state of discomfort for the teacher and deprivation them of their professional and personal selfdevelopment.

In order to study the first pedagogical condition, it is advisable to turn to the theory of the compensatory mechanism, according to which insufficient professional abilities are compensated with high interest and awareness of the chosen specialty. Based on such considerations, the scholar R. Horbatiuk claims that motivation is the main factor that drives the individual to be active and precedes the achievement of positive results ${ }^{17}$.

During the project technology, taking into account its main stages (search, modelling, organizational and management, design) ${ }^{18}$, we clearly understood the purpose of implementation of this innovation. In our view, the aim should be to design the educational process, which is expressed in such a new formation as a pedagogical project and to reflect in its content the unity of theory and practice.

That is, the combination of motives and goals becomes an important factor in the formation of the motivational sphere. And for the formation of its own vector, which gives rise to the initial impetus to pedagogical design, the preliminary study of the outside world and linking the future project with real life problems stands out ${ }^{19}$. Such a reflection consits in the teacher's

\footnotetext{
16 Жаркова Н.П. Организационные и психологические условия педагогического проектирования при реализации компетентносного похода к образованию. Известия Тульского государственного университета. Тула, 2008. С. 270.

17 Горбатюк P.M. Теоретико-методичні засади професійної підготовки майбутніх інженерів-педагогів комп'ютерного профілю : автореф. дис. ... д-ра пед. наук : 13.00.04. Тернопіль, 2011. С. 39.

18 Колодійчук Л.С. Етапи педагогічного проектування навчального процесу. Молодь і ринок. Педагогічні науки. Дрогобич, 2009. Вип. 6 (53). С. 48-50.

19 Жаркова Н.П. Организационные и психологические условия педагогического проектирования при реализации компетентносного похода к образованию. Известия Тульского государственного университета. Тула, 2008. С. 271.
} 
desire to identify and overcome the contradictions on one's own and helps to form a stable motive.

The relevance of the second organizational and pedagogical condition is due to the importance of educational and methodological complex of electrical disciplines and specialties, as a semantic component of the design of the educational process. After all, pedagogical design is always based on the content, as an internal feature of electrical knowledge, and focused on the relevant knowledge and personal qualities that must be obtained and formed in the learning process.

Thus, designing the optimum maintenance of electrotechnical knowledge assumes consistent and purposeful accumulation of students' knowledge, mastering of which actively helps to replenish their new knowledge.

In the course of the research it was discovered that the design of the system of knowledge of students in electrical engineering disciplines (the semantic component of the educational process) should take into account the following factors: features of the electrical industry in the agricultural sector; structuring of educational material on the basis of regularities of functioning of electrical engineering and power engineering; trends in the development of agro education; training in the system of continuing agricultural education. The key factor that forms the basis of professional training is to take into account the peculiarities of the electrical engineering specialty in the agricultural sector of the economy.

It is also important when designing the content of disciplines in agrotechnical institutions of higher education to establish links between university disciplines and their individual modules. This includes integrating the content of vocational electrical engineering disciplines, as well as identifying links with related natural sciences in colleges and schools. In particular, the harmonization of the content of training curricula in institutes, colleges and schools in the context of the introduction of specialized courses with the approximation to the level of modern electrical technologies. This position pursues the goal of early motivation of students with an emphasis on the activities of the future specialist in electrical engineering field.

This is confirmed in her research by V. Maksimova, and she determines that interdisciplinary links in purposeful and coordinated work are able to perform constructive functions, improving the content ${ }^{20}$ of academic disciplines, which helps to improve the quality of the educational process.

According to our research, the design of the semantic component should be fulfilled in both theoretical and practical directions. In particular, at designing the content of theoretical classes the concept of advanced learning

20 Максимова Н.В. Межпредметные связи и совершенствование процесса обучения: книга. Москва : Просвещение, 1984. С. 6. 
and shifting the emphasis from mathematization to the physical essence of technical processes should be taken into account. When designing the practical component, certification of laboratory jobs and focus on methods of activity, in particular, the leading components of training in technical specialties such as technical inspection, maintenance and overhaul, technology of installation and commissioning in agronomic facilities and production should be taken into consideration.

Thus, the second organizational and pedagogical condition indicates that the effectiveness of the design of the educational process largely depends on the success of solving problems related to the content.

The third organizational and pedagogical condition - the design of the procedural component of the educational process is based on the concept of "process" (development of qualitative change). It is connected with the focus of modern electrical engineering education on the individual needs of personal development and taking into account life experience.

As a result of such activities, the teacher is to design conditions that create a situation of success and active interaction of participants in the educational process. In particular, when designing the procedural component of the educational process, the teacher must design the conditions that ensure the optimal mode of education, upbringing and development of students. However, as O. Molchanyuk warns, the teacher's unwillingness to analyze the basic conditions of students' educational and cognitive activities can lead to the formalization of the process of mastering the material, restraining the creative potential of students and inhibiting the independence of the individual $^{21}$.

This position actualizes the tasks aimed at improving the procedural component of the educational process given the patterns of formation of the system of professional skills. This condition was realized by designing a system of skills with modern methodological tools that combine traditional (modular system) and innovative (design, distance, interactive methods) forms of students' learning process.

The fourth organizational and pedagogical condition is the design of the effectiveness component of the educational process on the basis of the competence approach.

Designing the effective component of the educational process determines the result of training future specialists in electrical engineering - the gradual formation of professional competence. After all, professional competencies are acquired in stages. In particular, a set of general, integral and

21 Молчанюк О.В. Проектування засобів оптимізації процесу навчання 3 природничих дисциплін у вищих навчальних закладах I-II рівнів акредитації : дис. ... к-та пед. Наук : 13.00.09. Харків, 2005. С. 151. 
professional competencies for a particular educational and professional program, allow to provide program learning outcomes.

This condition is revealed by us in the educational process by modelling the professional activities of future specialists in electrical engineering, designing independent work of students, designing a degree of assessment of students' knowledge of academic disciplines.

Choosing the most fruitful ways that create an effective impact on the formation of professional competence of future graduates of electrical engineering faculties, the arguments presented by researcher O. Pometun were taken into account. Thus, the author believes that one of the main tasks of education is to teach find the right solutions in specific situations: initial, life, then professional ${ }^{22}$.

In this context, modelling of professional activity in the educational process was gradually accomplished through: modelling of production situations for the implementation of integrative relations (creative tasks in the specialty of theoretical and simulation, a set of professionally oriented tasks that are closest to the production sphere; modelling technical processes (course project) and system modelling (diploma project).

When granting the effectivness component of designing the educational process of training of future specialists in electrical engineering, we used several methods: solving non-standard problems, independent work of various levels of complexity in preparation for the All-Ukrainian Olympiads in the specialty, educational projects, poster presentations and more. That is, in designing such a component of the educational process, we helped to create students' interest in learning, which is the basis of their professional development. And interest is possible if you give the educational process a competency orientation.

First of all, in the course of training a future specialist in electrical engineering, it is important to create conditions in which they are in a variety of production situations and from which they find a way out. We noticed that under the influence of these factors, especially modelling of production situations, and depending on the results of their own educational and cognitive activities, the student changes so that with the new competencies they discard their own uncertainty and are able to come to correct decisions in solving electrical problems in atypical situations.

In particular, the production situation is perceived and understood by a future specialist as a task that requires an answer to a certain technical question. At the same time, it appears as a problematic situation, i.e. a contradiction between the

${ }^{22}$ Пометун О.І. Компетентнісний підхід - найважливіший орієнтир розвитку сучасної освіти. Рідна школа. Педагогічні науки. 2005. № 1(900). С. 66. 
already obtained knowledge of a student at the given moment and the knowledge which they are only heading to obtain. To solve such situations, a future specialist must understand the problem and use active mental actions, which include logical operations: analysis and synthesis, induction and deduction, abstraction, comparison, generalization, etc.

That is, the solution of problems for the training of future specialists in electrical engineering in an agricultural institution of higher education, with high professional competence, with non-standard thinking, directly depends on the design of the effectiveness component of the educational process.

And finally, the fifth organizational and pedagogical condition information and material support of the educational process.

It is due to the importance of information technology in the agrotechnical institution of higher education in the formation of professional competencies of future specialists in electrical engineering. In particular, the expansion of information technology through the use of the graphical environment Labview, which today is one of the most convenient and affordable software products. In addition, the Labview environment is completely graphical, which contributes to the implementation of the principle of clarity in learning. A fragment of the development of a virtual device for controlling the feed preparation unit in the graphical environment Labview is presented in Figure 3.

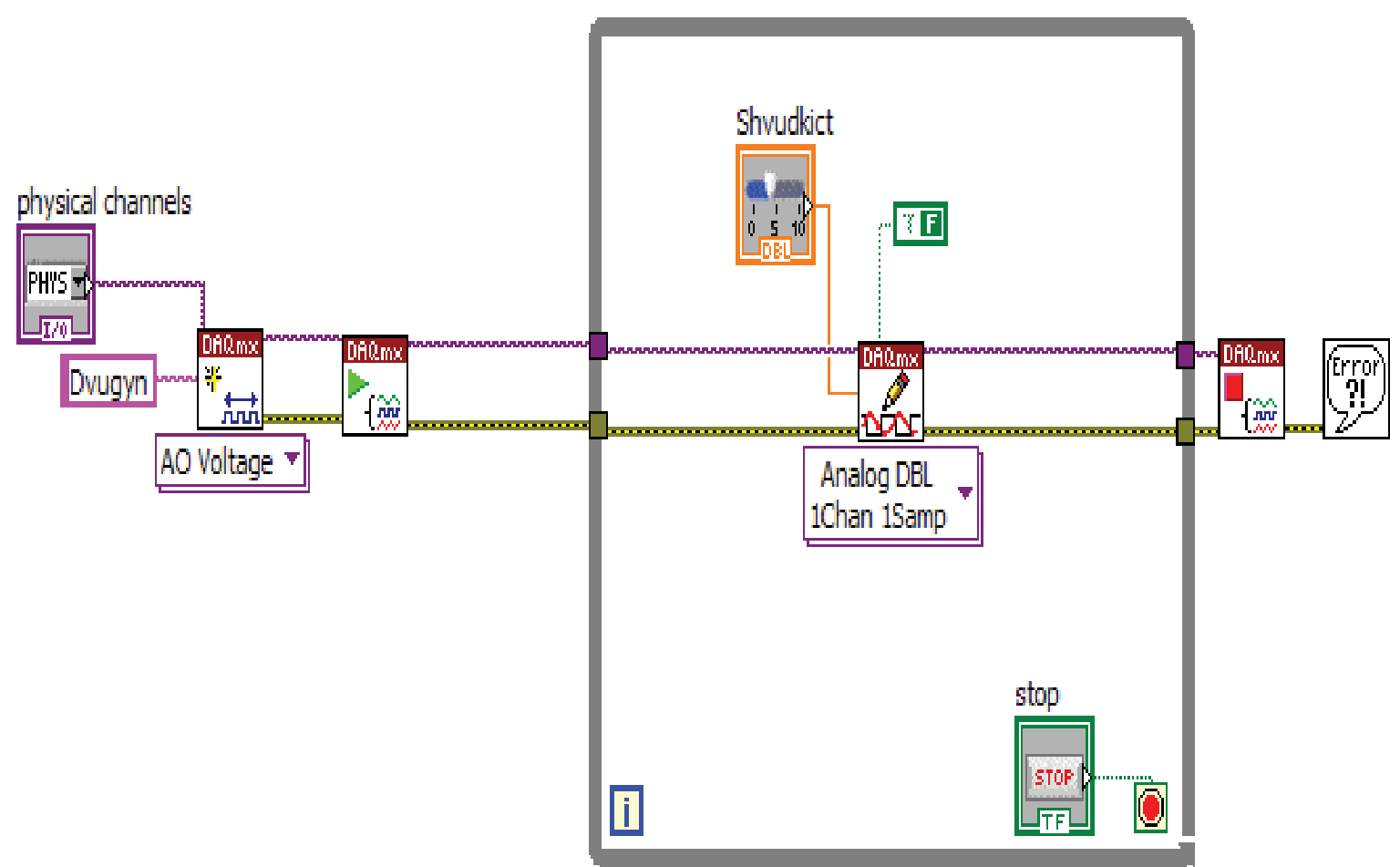

Fig. 3. Block diagram of the virtual device for controlling the speed of rotation of the electric motor of the feed machine in the graphical environment Labview 


\section{CONCLUSIONS}

Thus, the effectiveness of design and improvement of the educational process of training future specialists in electrical engineering depends on the conditions which are to support pedagogical projecting. In particular, considering the conditions as a component of the pedagogical system, it is proved that the achievement of positive results in project activities is determined by the following organizational and pedagogical conditions:

a) the formation of motivational readiness of teachers of agricultural institutions of higher education (the basis for the implementation of the condition is combination of motives and design goals);

b) designing the system of knowledge of students in electrical engineering disciplines (the semantic component of the educational process), which form the basis of professional training, taking into account the peculiarities of electrical engineering in the agricultural sector of the economy;

c) designing the system of skills (the procedural component of the educational process) through modern methodological tools, which provides a combination of traditional and innovative forms of learning (modular system, distance learning, project learning, interactive methods;

d) gradual formation of professional competence (the effectiveness component of the educational process) of future specialists in electrical engineering on the basis of the competence approach involves: modelling of professional activities through modelling of production situations (a set of professionally oriented and creative tasks in the specialty closest to the electrical field), modelling technical processes (course project paper) and system modelling (diploma project paper); independent activity of students; graded assessment of students' knowledge;

e) information and material support of the educational process by expanding the functions of information technology (graphical environment Labview).

Implementing of the experimental research on the basis of realization of the allocated organizational and pedagogical conditions, in our opinion, will allow to design components of educational process of professional training of future specialists of electrotechnical profile as an integral pedagogically organized system.

To the prospects of further pedagogical researches we include the development of a system of designing and improving the educational process of training future specialists in electrical engineering in an agricultural institution of higher education. 


\section{SUMMARY}

The article deals with the organizational and pedagogical conditions for designing the educational process of training future specialists in electrical engineering. Five organizational and pedagogical conditions have been identified and substantiated: formation of motivational readiness of teachers of agrotechnical institutions of higher education for project activities; designing the system of students' knowledge in electrical engineering disciplines (the semantic component of the educational process), which form the basis of professional training, taking into account the peculiarities of electrical engineering in the agricultural sector of the economy; designing the system of skills (procedural component of the educational process) through modern methodological tools, which provides a combination of traditional and innovative forms of teaching and learning (modular system, project-based learning, interactive methods; gradual formation of professional competence (resultant component of the educational process) of the future specialist in electrical engineering on the basis of the competence approach (modelling the professional activity; independent activity of students; graded assessment of knowledge); information and material support of educational process by expanding the functions of information technology (graphical environment Labview).

\section{REFERENCES}

1. Буцик I.M. Шляхи забезпечення організаційно-педагогічних умов розвитку дослідницької компетентності майбутніх фахівців 3 агроінженерії в процесі вивчення сільськогосподарських машин. Інноваційна педагогіка. Педагогічні науки. Одеса, 2019. Вип. 11, том 1. C. 56-60.

2. Волкова Н.П. Педагогіка : посібник. Київ : Академія, 2002. 576 с.

3. Горбатюк Р.М. Теоретико-методичні засади професійної підготовки майбутніх інженерів-педагогів комп'ютерного профілю : автореф. дис. ... д-ра пед. наук : 13.00.04. Тернопіль, 2011. 46 с.

4. Гуменюк В.В. Організаційно-педагогічні умови здобуття іноземними студентами вищої медичної освіти в Україні (середина XX - початок XXI століття) : автореф. дис. ... к-та пед. наук : 13.00.01. Хмельницький, 2016. 36 с.

5. Жаркова Н.П. Организационные и психологические условия педагогического проектирования при реализации компетентностного подхода к образованию. Вестник Тульского государственного университета. Тула, 2008. С. 266-276.

6. Кільдеров Д.Е. Теоретичні і методичні засади забезпечення якості підготовки майбутніх учителів технологій на основі інтегрованого навчання: дис. ... д-ра пед. наук: 13.00.04. Вінниця, 2018. 492. 
7. Колодійчук Л.С. Етапи педагогічного проектування навчального процесу. Молодь $i$ ринок. Педагогічні науки. Дрогобич, 2009. Вип. 6 (53). С. 48-50.

8. Кривильова О.А. Проектування психолого-педагогічної підготовки майбутніх викладачів професійно-технічних навчальних закладів : дис. ... д-ра пед. наук : 13.00.04. Бердянськ, 2018. 492.

9. Максимова Н.В. Межпредметные связи и совершенствование процесса обучения : книга. Москва : Просвещение, 1984. 143 с.

10. Молчанюк О.В. Проектування засобів оптимізації процесу навчання 3 природничих дисциплін у вищих навчальних закладах I-II рівнів акредитації: дис. ... к-та пед. наук: 13.00.09. Харків, 2005. 190.

11. Недбай М. П. Організаційно-педагогічні умови оптимізації викладання технічних дисциплін курсантами гуманітарного напряму підготовки. Збірник наукових праць. Педагогічні і психологічні науки. Хмельницький : НАДПС України, 2005. № 33. С. 87-89.

12. Пометун O.I. Компетентнісний підхід - найважливіший орієнтир розвитку сучасної освіти. Рідна школа. Педагогічні науки. 2005. № 1(900). С. 65-69.

13. Олексієнко Л.П., Шумейло О.Л. Сучасний тлумачний словник украӥнської мови. Київ : Кобза, 2002. С. 544.

14. Філософія словник. URL: https://arm.naiau.kiev.ua/books/ filosofia-30012017/info/slovnyk.html (дата звернення: 27.04.2020).

15. Шевченко А.В. Формування фахової компетентності майбутніх офіцерів тилу в процесі професійної підготовки : дис. ... к-та пед. наук : 13.00.04. Хмельницький, 2017. 230.

16. Чорнобрива Н.В. Підготовка майбутніх фельдшерів до професійної діяльності у процесі виробничої практики : дис. ... к-та пед. наук : 13.00.04. Хмельницький, 2018. 206.

17. Ярошинська О.О. Теоретико-методичні засади проектування освітнього середовища професійної підготовки майбутніх учителів початкової школи : дис. ... д-ра пед. наук : 13.00.04. Умань, 2015. 483.

\section{Information about the author: Kolodiichuk L. S.,}

$\mathrm{PhD}$ in Pedagogic Sciences, Head of the Department of Electrotechnologies and Operation of Energy Equipment of Separated Subdivision National University of Life and Environmental Sciences of Ukraine "Berezhany Agrotechnical Institut" 20, Academichna str., Berezhany, Ternopil region, Ukraine 